TEME, г. XLIV, бр. 4, октобар - децембар 2020, стр. 1123-1135

\begin{tabular}{lr}
\hline \hline Оригинални научни рад & https://doi.org/10.22190/TEME191106076K \\
Примљено: 6. 11. 2019. & UDK 343.91-053.5/.6 \\
Ревидирана верзија: 7. 2. 2020. & 159.922 .8 \\
Одобрено за штампу: 1. 12. 2020. &
\end{tabular}

\title{
PEER PRESSURE AND ACADEMIC ACHIEVEMENT AS PREDICTORS OF ADOLESCENT RISK BEHAVIORS
}

\author{
Olivera Knežević Florić”, Aleksandra Pavlović, Stefan Ninković \\ University of Novi Sad, Faculty of Philosophy, Novi Sad, Serbia \\ *florico@ff.uns.ac.rs
}

\begin{abstract}
Understanding the factors associated with adolescent risk behaviors is an important research topic in Serbia. The aim of this study was to examine whether peer pressure and academic achievement predict adolescent risk behaviours such as cigarette smoking, drinking alcohol, marijuana use and unprotected sex. The data was collected from 181 (68\% female) second-grade students of two secondary schools. The questionnaire for assessing peer pressure, risk behaviors, as well as socio-demographic variables was applied. Logistic regression analysis revealed that the perceived peer pressure and academic achievement both predict various types of risky behaviors among adolescents. The findings of this study can have implications for improving the prevention of risktaking behaviors in adolescence.
\end{abstract}

Key words: $\quad$ risk taking, adolescents, peer influence, peer pressure, academic achievement.

\section{ВРШЫАЧКИ ПРИТИСАК И АКАДЕМСКО ПОСТИГНУЋЕ КАО ПРЕДИКТОРИ РИЗИЧНОГ ПОНАШАЊА АДОЛЕСЦЕНАТА}

\begin{abstract}
Апстракт
Разумевање фактора који су повезани са ризичним понашањима адолесцената представља важну истраживачку тему у Србији. Циљ овог рада био је испитивање да ли вршњачки притисак и академско постигнуће представљају предикторе ризичних понашања адолесцената, као што су пушење, конзумирање алкохола, конзумирање марихуане и ступање у незаштићене сексуалне односе. Подаци су прикупљени на узорку од 181 (68\% женског пола) ученика другог разреда две средње школе. Примењен је упитник намењен испитивању вршњачког притиска и ризичних понашања адолесцената, као и социодемографских варијабли. Логистичка регресиона анализа показала је да опажени вршњачки притисак и академско постигнуће предвиђају поједине облике ризичних понашања адолесцената. Резултати истраживања имају импликације за унапређење превенције ризичних понашања у адолесценцији. Кључне речи: ризиковање, адолесценти, утицај вршњака, вршњачки притисак, академско постигнуће.
\end{abstract}




\section{INTRODUCTION}

The results of the empirical research have demonstrated that adolescence is a period of a heightened propensity toward risk taking that may endanger the health and well-being of the individual and those in his or her environment (Duell et al., 2018). For this reason, various strategies have been developed to prevent adolescent risk behaviors. Numerous prevention programs have been focused on providing information to adolescents about the harmful effects of certain behaviors (Steinberg, 2008). However, scientists have found that adolescents are capable of assessing the risks of their behavior (Smith, Chein, \& Steinberg, 2014). What sets adolescents apart from adults are rapid developmental changes, rebellion, need for autonomy and freedom (Luthar \& Ansary, 2005) and the unique susceptibility to peer influences (Albert \& Steinberg, 2011).

Epidemiological and experimental studies have indicated that adolescents are more inclined to take risks when they are in the presence of their peers than when they are alone (Gardner \& Steinberg, 2005) or in the presence of the adults (Smith et al., 2015). This phenomenon known as peer effect has not been noticed among adults (Albert, Chein, \& Steinberg, 2013). The presence of peers increases adolescents' propensity to engage in risk behaviors and the likelihood of supporting risky choices in hypothetical decision-making scenarios (Gardner \& Steinberg, 2005).

Academic achievement has been identified as a protective factor that contributes to the positive social development of children and young people (Maguin \& Loeber, 1996). Numerous empirical studies show that there is a negative correlation between school achievement and risky behavior (McEvoy \& Welker, 2000; Santor, Messervey, \& Kusumakar, 2000). However, given that there is generally a decline in academic motivation in adolescence (Gnambs \& Hanfstingl, 2016), there is a need to explore the relationship between high school students' academic performance and risk behavior.

\section{ADOLESCENT RISK BEHAVIORS}

Risk behaviors increase the likelihood of a specific adverse outcome, and have potentially negative consequences on the person who manifests such behaviour and his or her environment (Ricijaš, Krajcer, \& Bouillet, 2010). In epidemiological studies, risk taking is widely conceptualized as engaging in behaviors that may compromise the health or well-being of the individual and those in the environment (Hawley, 2011). Unlike the risk taking propensity, which is usually examined by the use of laboratory tasks that minimize contextual influences, real risk taking is usually measured by self-reported surveys. Real-world risk taking is influenced by cultural norms that increase or decrease the chances for adolescents to engage in risky activities (Duell et al., 2018). 
The results of empirical research have not supported stereotypes about adolescents' irrationality. There is evidence that the logical reasoning ability of 15-year-olds is comparable to the logical reasoning ability of adults (Reyna \& Farley, 2006). This means that adolescents perceive risk and their own vulnerability at the same level as adults. In addition, adolescents report a level of risk discomfort comparable to level of risk discomfort reported by adults (Steinberg, 2008). These findings suggest that risky decision making of adolescents is not caused by their lack of cognitive competencies.

The dual system model provides the insights that are important for understanding adolescents' propensity to engage in risk behaviors (Botdorf, Rosenbaum, Patrianakos, Steinberg, \& Chein, 2017; Steinberg, 2008). This model postulates that adolescents' increased participation in risk behaviors is due to the imbalanced maturation of the cognitive-control system and the socio-emotional system that regulates rewards, emotions, and social cognition. Unlike logical reasoning ability, which is mainly developed by the age of 15 or 16 , psychosocial capacities that enhance decision making, such as impulse control, emotional regulation, resilience to peer influence, continue to develop. Therefore, adolescents sometimes manifest poor decision-making competence, despite the fact that they are able to understand the costs and benefits of their choices (Albert \& Steiberg, 2011).

In addition, adolescents are often confronted with stress resulting from the many developmental tasks that they face. Adolescents are expected to be responsible and make some important decisions, but they still have to admit that they are not equal to the adults (Toledo-Rodriguez \& Sandi, 2011). Also, in order to show independence and to distance themselves from parental control and other adults, adolescents are prone to rebelliousness that manifests itself through different types of risky behavior (Luthar \& Ansary, 2005). Thus, although adolescents have information about the harms of certain behaviors and cognitive decision-making maturity, they are not as capable as adults of making the right decisions about risky behavior.

\section{PEER PRESSURE AND ACADEMIC ACHIEVEMENT AS PREDICTORS OF ADOLESCENT RISK BEHAVIORS}

Social relationships are a powerful context of socialization and identity formation during adolescence. Peer groups influence social behavior in adolescence by allowing young people to explore individual interests while having a sense of belonging to a group of friends (Forko \& Lotar, 2012). Although peers can encourage prosocial behaviors (Van Hoorn, Van Dijk, Meuwese, Rieffe, \& Crone, 2015), for many young people, substance use, delinquency, and sexual activity may represent efforts to 
conform the group norms and to demonstrate commitment and loyalty to other group members (Santor et al., 2000). It is well known that association with peers who exhibit delinquent behavior, drink alcohol or use drugs can lead to deviant behavior in adolescents (Monahan, Steinberg, \& Cauffman, 2009). In addition, adolescents are at greater risk of being involved in a car accident while driving with peers (Albert et al., 2013).

Peer influence is not a unique phenomenon and it can take on many different forms. The most common type of peer influence is the modeling of attitudes or behaviors, where adolescents observe and adapt social norms from the valued group of peers. Another recognized form of influence is hostile behavior, which includes teasing, mocking, intimidation, disparagement, and even threats and physical aggression. Behavioral empowerment is also a form of peer influence, where peers reward, praise, or reinforce certain risk behaviors. Another form of influence is the creation of opportunities, which does not imply direct encouragement but the creation of an environment conducive to some forms of risk taking (Forko \& Lotar, 2012).

Peer pressure can be defined as "subjective experience of feeling pressured, urged, or dared by others to do certain things" (Santor et al., 2000 , p. 166). The susceptibility of young people to peer pressure depends on various factors, such as the degree of encouragement of child's autonomy in the family, maternal support, the degree of social skills development, and the level of social popularity of their close firends (Allen, Chango, Szwedo, Schad, \& Marston, 2012).

Recent research has shown that displaying risk behaviors in the presence of peers is conditioned by adolescents' social and affective sensitivity (Steinberg, 2008). The presence of peers makes adolescents responsive to rewards, increasing the subjective value of the immediate benefits of risky choices over long-term safe alternatives. Adolescents are more willing to inhibit their impulses in neutral conditions than in situations characterized by emotional arousal. Emotional arousal can compromise or overcome an under-mature control system, leading to risk behaviors (Botdorf et al., 2016).

Although school achievement in adolescence is important for future educational success, adolescence is often associated with a trend of decreased academic motivation and success in school (Wang \& Fredricks, 2014). Negative school-related experiences are a factor that contributes to risk behaviors (Hawkins, Catalano, \& Miller, 1992; Petraitis, Flay, \& Miller, 1995). Wang and Fredricks (2014) have found longitudinal bidirectional relations between behavioral and emotional engagement with school and adolescent delinquency and substance use. Frequent use of marijuana is associated with lower average grades, school dissatisfaction, negative attitudes toward school, and other risk behaviors in the school environment (Bergen, Martin, Roeger, \& Allison, 2005). 
Numerious studies have demonstrated that academic motivation is an important protective factor against engagement in problem behaviours (Wheeler, 2010). One of the mechanisms that mediates the relationship between school achievement and adolescent misbehaviors is school attachment (Hoffmann, Erickson, \& Spence, 2013). The social bond theory (Hirschi, 1969) postulates that, when young people are committed to school and engaged in conventional school activities, they will less likely manifest risky behaviors. Strong attachment to school develops motivation to adopt prosocial values, norms and goals that are affirmed in the school environment. Commitment to school responsibilities has a positive impact not only on the students' behavior, but also on their future academic achievement.

\section{METHODS}

\section{Aims of Research}

According to our knowledge, the relationship between peer pressure, academic achievement, and adolescent risk behaviors has not been investigated in Serbia so far. Therefore, this research had two main objectives:

1. to explore the rates of the various types of risky behaviors of adolescents.

2. to examine the relationship between gender, school type, academic achievement and the perceptions of peer pressure, on the one hand, and adolescent risk behaviors, on the other.

\section{Sample}

Data were gathered from 181 second-grade vocational $(N=104$, $57 \%)$ and gymnasium $(N=77,43 \%)$ students. The sample included 58 (32\%) male and $123(68 \%)$ female students. Out of the total number of respondents, $56(31 \%)$ live in the village or town, while $125(69 \%)$ live in the city. The structure of respondents according to family completeness is as follows: 154 (85\%) of respondents are from complete, while $27(15 \%)$ of respondents come from incomplete families. In $93(51 \%)$ of the respondents, the father has completed secondary education, while in 88 (49\%) the father has higher education. When it comes to the education of mothers, $79(44 \%)$ of respondents have secondary education, and in 102 $(56 \%)$ of them the mother has higher education. Out of the total number of respondents, $73(40 \%)$ have excellent success, $74(41 \%)$ are very good, $9(16 \%)$ are good, none $(0 \%)$ is sufficient and $5(3 \%)$ have poor succes. 


\section{Procedure}

The survey was conducted in one high school of economics and one gymnasium in Novi Sad, in May and June 2018. One of the authors of the paper, after obtaining the approval of the school management, realized the data collection using a standard paper-and-pencil procedure. Data collection was anonymous and all respondents voluntarily participated in the survey.

\section{Instruments}

Data on the sociodemographic characteristics of the respondents were collected through the use of a questionnaire that included questions about the students' gender, place of residence, type of school they attend, academic achievement, family structure, and parental education. The students' academic achievement was operationalized as the grade point average at the end of the first semester of the 2017/2018 school year.

Percieved peer preasure was measured using the scale developed by Santor et al. (2000). This instrument assumes that peer pressure is a unidimensional construct. Participants responded using a five-point Likert scale ranging from strongly disagree (1) to strongly agree (5). The reliability of the scale in this study was adequate (Cronbach's alpha coefficient was .77).

Adolescent risk behaviors were assessed using a questionnaire that contained questions about cigarette smoking, drinking alcohol, marijuana consumption and unprotected sexual intercourse. These risk behaviors were chosen because of the assumed relevance of peer pressure for them. Consistent with previous research (Cornell \& Huang, 2016), the items related to adolescent risk behaviors have been dichotomized in such a way that a value of 1 indicates a particular risk behavior. This gave an insight into whether the respondents were involved in particular risk activities in the last six months.

\section{Data Analysis}

The obtained data were analyzed using IBM SPSS (version 23) software. The data analysis included descriptive statistical analysis, as well as the application of binary logistic regression.

\section{RESULTS}

Our first research question was to examine the rates of different types of adolescent risk behaviors (Figure 1). Frequency analysis showed that drinking alcohol was the most common risk behavior $(N=160)$, followed by cigarette smoking $(N=67)$, unprotected sex $(N=17)$, and marijuana use $(N=17)$. 


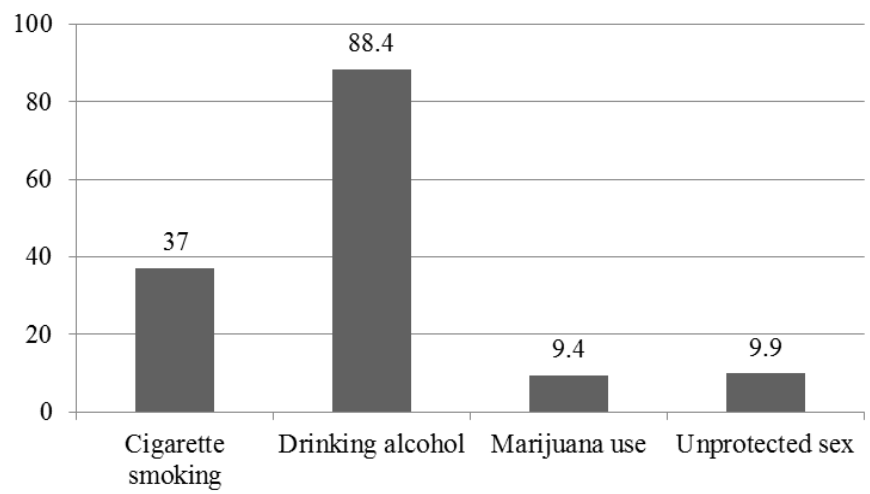

Figure 1. The percentage of adolescents engaged in risk behaviors

In the first logistic regression, the variables gender, school type, academic achievement, and perceived peer pressure were introduced as the predictors, while the criterion variable was cigarette smoking. The whole model was statistically significant, $\chi^{2}(4, N=181)=41.10, p<.001$, and the percentage of explained variance was 27.7. Based on the partial regression coefficients shown in Table 1 , it can be concluded that academic achievement decreases the probability of cigarette smoking. On the other hand, the perception of peer pressure was a positive predictor of this type of risky behavior.

Table 1. Logistic regression results for cigarettes smoking

\begin{tabular}{lcccccc}
\hline Predictors & $B$ & Wald & $p$ & $\operatorname{Exp}(B)$ & $95 \%$ confidence intervals \\
\hline Sex & 0.57 & 2.13 & .145 & 1.77 & 0.82 & 3.83 \\
Type of school & -0.64 & 2.34 & .126 & 0.53 & 0.24 & 1.20 \\
Academic achievement & -0.54 & 4.60 & .032 & 0.58 & 0.36 & 0.96 \\
Peer pressure & 0.15 & 22.47 & .000 & 1.16 & 1.09 & 1.23 \\
\hline
\end{tabular}

The model that contained drinking alcohol as a criterion variable was also statistically significant, $\chi^{2}(4, N=181)=13.59, p<.01$. However, none of the analyzed predictors had a statistically significant contribution (Table 2). This result may be due to the fact that the type of school variable achieved a marginally significant effect $(p=.052)$.

Table 2. Logistic regression results for drinking alcohol

\begin{tabular}{lrrrrrc}
\hline Predictors & $B$ & Wald & $p$ & $\begin{array}{c}\text { Exp } \\
(B)\end{array}$ & $95 \%$ confidence intervals \\
\hline Sex & 0.42 & 0.71 & .399 & 1.52 & 0.57 & 4.03 \\
Type of school & -1.20 & 3.78 & .052 & 0.30 & 0.09 & 1.01 \\
Academic achievement & -0.60 & 1.24 & .266 & 0.55 & 0.19 & 1.58 \\
Peer pressure & 0.03 & 0.64 & .425 & 1.03 & 0.96 & 1.11 \\
\hline
\end{tabular}


In the following binary logistic regression, marijuana consumption was introduced as a criterion variable (Table 3 ). This analysis indicated the overall model was significant, $\chi^{2}(4, N=181)=15.49, p<.01$, and explained a substantial amount of the variance in marijuana use. Perceieved peer pressure was a significant predictor of marijuana use.

Table 3. Logistic regression results for using marijuana

\begin{tabular}{lrrcccc}
\hline Predictors & $B$ & Wald & $p$ & $\operatorname{Exp}(B)$ & $95 \%$ & confidence intervals \\
\hline Sex & -0.92 & 2.72 & .099 & 0.40 & 0.13 & 1.19 \\
Type of school & 0.32 & 0.23 & .636 & 1.37 & .37 & 5.08 \\
Academic achievement & -0.49 & 1.89 & .169 & 0.61 & 0.31 & 1.23 \\
Peer pressure & 0.11 & 10.88 & .001 & 1.11 & 1.05 & 1.19 \\
\hline
\end{tabular}

When predicting unprotected sexual intercourse as a criterion variable, a statistically significant model was obtained, $\chi^{2}(4, N=181)=$ $15.34, p<.01$, and the proportion of explained variance was $17 \%$. As shown in Table 4 , based on the negative sign of the partial regression coefficient for the sex variable, it can be concluded that adolescent girls were less prone having unprotected sex. The partial logistic regression coefficients for academic achievement and peer pressure were statistically significant. With increasing academic achievement, the probability of engaging in risk sexual behaviors decreases. On the other hand, the perception of peer pressure significantly increases the likelihood of engaging in unprotected sex.

Table 4. Logistic regression results for unprotected sex

\begin{tabular}{lrccccc}
\hline Predictors & \multicolumn{1}{c}{$B$} & Wald & $p$ & $\operatorname{Exp}(B)$ & 95\% confidence interval \\
\hline Sex & -1.49 & 7.20 & .007 & 0.23 & 0.08 & 0.67 \\
Type of school & 0.39 & 0.36 & .549 & 1.48 & 0.41 & 5.40 \\
Academic achievement & -0.74 & 4.84 & .028 & 0.48 & 0.25 & 0.92 \\
Peer pressure & 0.07 & 4.56 & .033 & 1.07 & 1.01 & 1.14 \\
\hline
\end{tabular}

\section{DISCUSSION}

Adolescents' risky behavior has been long recognized as a major public health concern worldwide (Duell et al., 2018). Knowing the factors that influence adolescent risk taking is an important prerequisite for creating successful prevention programs. Thus, the main objective of this research was to better understand the relationship between academic achievement, perceived peer pressure, and adolescent risk behaviors.

In line with previous studies (Marić, 2011; Spremo, Letić i MarkovićBasara, 2016) this study showed that drinking alcohol is the most common risk behavior among adolescents. It is quite likely that young people consider this behavior less dangerous than unprotected sexual 
intercourse or using marijuana and other psychoactive substances. Also, this result can be linked to the cultural context of Serbia which is characterized by the availability and social acceptance of alcohol. Nevertheless, it should be noted that risk behaviours are linked (Wheeler, 2010) and thus drinking alcohol can be associated with other forms of risk taking among adolescents.

It is important to consider the relationship between peer pressure and adolescent risk behaviors. In line with previous studies (Monahan et al., 2009; Santor et al, 2000), the results of this study showed that peer pressure is a significant predictor of cigarette smoking, marijuana use, and risky sexual behavior. Santor et al. (2000) have demonstrated that the perception of peer pressure contributes to alcohol, drug and cigarette consumption, as well as poorer academic achievement. Recent empirical findings indicate that the mere presence of peers increases the adolescents' need to take risks (Gardner \& Steinberg, 2005). One possible explanation for this result is the relationship between peer relationships and adolescent social behavior. Peer pressure can have direct forms, such as persuasion, verbal encouragement, or teasing (Forko \& Lotar, 2012). Additionally, peer pressure can be subtler in nature, such as encouraging oneself to engage in risky activities and thus conforming to peer's norms to gain social approval and avoid rejection (Kiuru, Burk, Laursen, Salmela-Aro, \& Nurmi, 2010). This means that risk taking can only be associated with popularity and high social status when social norms of the peer group support such behaviors.

The results of this study demonstrated that academic achievement had effects on the probability of cigarettes smoking and engaging in risky sexual intercorses. Previous research (Wang \& Fredricks, 2014) has found that disengagement from school is actually a risk factor that can lead to adolescents' involvement in problem behaviours. It is also possible that low school achievement and risky behaviour have some common causes (Hoffmann et al., 2013). Some of the factors that may be associated with poor academic performance and risk taking are poverty, negative peer influence and dysfunctional parent-child relationships.

In this study gender did not have a significant effect on the likelihood of smoking cigarettes, drinking alcohol, and marijuana use. This result appeared to be in line with some previous studies that suggest that drinking patterns are less differentiated by gender in adolescence compared to adulthood (Ahlström \& Österberg, 2004) and that there are no significant gender differences regarding adolescent smoking (Piko \& Balázs, 2012). Nevertheless, it was found that adolescent girls are less prone to having sexual intercourse without protection. This is consistent with previous findings that have indicated that adolescent females tend to worry more about unplanned pregnancy compared to males (Dir, Coskunpinar, \& Cyders, 2014). 
This research raises several new questions that may be the focus of future research. First of all, in addition to academic performance and peer pressure, other potential predictors of adolescent risk behaviors need to be examined. Also, in order to improve the external validity of research findings, it would be useful to examine the determinants of youth risky behavior on a larger sample. Finally, it should be emphasized that this study used instruments based solely on adolescents' self-assessments. In this regard, it would be desirable that future studies include alternative measures of the inclination of young people in Serbia to participate in risky behaviors.

\section{CONCLUSION}

During adolescence, peers inevitably play a significant role in a young person's life. Peer friendships give young people a lot of positive opportunities despite the negative connotations. Peer relationships are really important for healthy development and are essential for young people to grow into a healthy adult. Yet, peer relationships also have the potential to encourage risky behavior. The results of the research once again confirmed the association between peer pressure and academic achievement with adolescent risk behavior. Given the fact that peer influence (and pressure) cannot be avoided, it is important to focus preventative efforts on peer groups.

Risky behaviors have become widespread among adolescents in Serbia (see Marić, 2011). Prevention strategies that aim to provide information through lectures are not enough since they have usually failed to change youth behavior (Steinberg, 2008). Given the findings of this study, we believe that more attention should be paid to prevention programs within peer environments. Peer education is a promising prevention approach since risky behaviors may be related to young people's efforts to achieve high status in the peer group. Adolescents are more likely to hear and personalize messages, and thus change their attitudes and behaviors if they believe that the one sending the message is similar to them and faces the same concerns and pressures.

In addition to peer influence, low academic achievement is a significant risk factor. The implications of the present research are related to the prevention of adolescent risky behaviors, which includes promoting academic performance and school attachment. The results presented above suggest that low academic achievement is a significant predictor of different types of risk behaviors. On the other hand, high academic achievement and a positive attitude towards the school, as well as support from the school, parents and peers, are significant protective factors. The challenge for researchers, as well as for all those involved in the prevention and promotion of healthy outcomes for young people, is how to design programs that best target these risks and protective factors. 


\section{REFERENCES}

Ahlström, S. K., \& Österberg, E. L. (2004). International perspectives on adolescent and young adult drinking. Alcohol Research and Health, 28, 258-268.

Albert, D., Chein, J., \& Steinberg, L. (2013). Peer influences on adolescent decision making. Current Directions in Psychological Science, 22(2), 114-120. doi: $10.1177 / 0963721412471347$

Albert, D., \& Steinberg, L. (2011). Judgment and decision making in adolescence. Journal of Research on Adolescence, 21(1), 211-224. doi: 10.1111/j.15327795.2010.00724.x

Allen, J. P., Chango, J., Szwedo, D., Schad, M., \& Marston, E. (2012). Predictors of susceptibility to peer influence regarding substance use in adolescence. Child Development, 83(1), 337-350. doi: 10.1111/j.1467-8624.2011.01682.x

Bergen, H. A., Martin, G., Roeger, L., \& Allison, S. (2005). Perceived academic performance and alcohol, tobacco and marijuana use: longitudinal relationships in young community adolescents. Addictive Behaviors, 30(8), 1563-1573. doi: 10.1016/j.addbeh.2005.02.012

Botdorf, M., Rosenbaum, G. M., Patrianakos, J., Steinberg, L., \& Chein, J. M. (2017). Adolescent risk-taking is predicted by individual differences in cognitive control over emotional, but not non-emotional, response conflict. Cognition and Emotion, 31(5), 972-979. doi: 10.1080/02699931.2016.1168285

Cornell, D., \& Huang, F. (2016). Authoritative school climate and high school student risk behavior: A cross-sectional multi-level analysis of student self-reports. Journal of Youth and Adolescence, 45(11), 2246-2259. doi:10.1007/s10964016-0424-3

Dir, A. L., Coskunpinar, A., \& Cyders, M. A. (2014). A meta-analytic review of the relationship between adolescent risky sexual behavior and impulsivity across gender, age, and race. Clinical Psychology Review, 34(7), 551-562. doi: 10.1016/j.cpr.2014.08.004

Duell, N., Steinberg, L., Icenogle, G., Chein, J., Chaudhary, N., Di Giunta, L., \& Chang, L. (2018). Age patterns in risk taking across the world. Journal of Youth and Adolescence, 47, 1052-1072. doi: 10.1007/s10964-019-00999-z.

Forko, M., \& Lotar, M. (2012). Izlaganje adolescenata riziku na nagovor vršnjaka važnost percepcije sebe i drugih [Adolescents' exposure at the urge of their peers - the importance of self-perception and perception of others]. Kriminologija i socijalna integracija, 20(1), 35-47.

Gardner, M., \& Steinberg, L. (2005). Peer influence on risk taking, risk preference, and risky decision making in adolescence and adulthood: an experimental study. Developmental Psychology, 41(4), 625-635. doi: 10.1037/00121649.41.4.625

Gnambs, T., \& Hanfstingl, B. (2015). The decline of academic motivation during adolescence: An accelerated longitudinal cohort analysis on the effect of psychological need satisfaction. Educational Psychology, 36, 1691-1705. doi:10.1080/01443410.2015.1113236

Hawkins, J. D., Catalano, R. F., \& Miller, J. Y. (1992). Risk and protective factors for alcohol use and other drug problems in adolescence and early adulthood: Implications for substance use prevention. Psychological Bulletin, 112(1), 64105. doi: 10.1037/0033-2909.112.1.64

Hawley, P. H. (2011). The evolution of adolescence and the adolescence of evolution: The coming of age of humans and the theory about the forces that made them. Journal of Research on Adolescence, 21, 307-306. doi: 10.1111/j.15327795.2010.00732.x 
Hirschi, T. (1969). Causes of delinquency. Berkeley, CA: University of California Press.

Hoffmann, J. P., Erickson, L. D., \& Spence, K. R. (2013). Modeling the association between academic achievement and delinquency: An application of interactional theory. Criminology, 51(3), 629-660. doi: 10.1111/1745-9125.12014

Kiuru, N., Burk, W. J., Laursen, B., Salmela-Aro, K., \& Nurmi, J. E. (2010). Pressure to drink but not to smoke: disentangling selection and socialization in adolescent peer networks and peer groups. Journal of Adolescence, 33(6), 801-812. doi: 10.1016/j.adolescence.2010.07.006

Luthar, S., \& Ansary, N. (2005). Dimensions of adolescent rebellion: Risks for academic failure among high- and low-income youth. Development and Psyscopatology, 17(1), 231-250.

Maguin, E., \& Loeber, R. (1996). Academic performance and delinquency. Crime and Justice, 20, 145-264. doi: 10.1086/449243

Marić, M. (2011). Socio-demografski činioci i upotreba psihoaktivnih supstanci u adolescenciji [Socio-demographic factors and substance use in adolescence]. Stanovništvo, 49(2), 91-113. doi:10.2298/STNV1102091M.

McEvoy, A., \& Welker, R. (2000). Antisocial behavior, academic failure, and school climate. Journal of Emotional and Behavioral Disorders, 8, 130-140. doi: $10.1177 / 106342660000800301$

Monahan, K. C., Steinberg, L., \& Cauffman, E. (2009). Affiliation with antisocial peers, susceptibility to peer influence, and antisocial behavior during the transition to adulthood. Developmental Psychology, 45(6), 1520-1530. doi:10.1037/a0017417.

Petraitis, J., Flay, B. R., \& Miller, T. Q. (1995). Reviewing theories of adolescent substance use: organizing pieces of the puzzle. Psychological Bulletin, 117, 67-86. doi: 10.1037/0033-2909.117.1.67

Piko, B. F., \& Balázs, M. Á. (2012). Authoritative parenting style and adolescent smoking and drinking. Addictive Behaviors, 37(3), 353-356. doi: 10.1016/j.addbeh.2011. 11.022

Reyna, V., \& Farley, F. (2006). Risk and rationality in adolescent decision-making: implications for theory, practice, and public policy. Psychological Science in the Public Interest, 7, 1-44. doi:10.1111/j.1529-1006.2006.00026.x

Ricijaš, N., Krajcer, M., \& Bouillet, D. (2010). Rizična ponašanja zagrebačkih srednjoškolaca-razlike s obzirom na spol [Risk behaviour of Zagreb high school students - gender differences]. Odgojne znanosti, 12(19), 45-63.

Santor, D. A., Messervey, D., \& Kusumakar, V. (2000). Measuring peer pressure, popularity, and conformity in adolescent boys and girls: Predicting school performance, sexual attitudes, and substance abuse. Journal of Youth and Adolescence, 29(2), 163-182. Doi: 10.1023/A:1005152515264

Smith, A. R., Chein, J., \& Steinberg, L. (2014). Peers increase adolescent risk taking even when the probabilities of negative outcomes are known. Developmental Psychology, 50(5), 1564-1568. doi: 10.1037/a0035696

Spremo, M., Letić, N. i Marković-Basara, T. (2016). Upotreba alkohola kod učenika srednjih škola [Alcohol consumption among high school students]. Biomedicinska istraživanja, 7(1), 51-57. doi: 10.7251/BII1601051S

Steinberg, L. (2008). Risk taking in adolescence: new perspectives from brain and behavioral science. Current Directions in Psychological Science, 16(2), 5559. doi: 10.1111/j.1467-8721.2007.00475.x

Toledo-Rodriguez, M., \& Sandi, C. (2011) Stress during adolescence increases novelty seeking and risk-taking behavior in male and female rats. Frontiers in Behavioral Neuroscience, 5, 1-10. doi: 10.3389/fnbeh.2011.00017 
van Hoorn, J., van Dijk, E., Meuwese, R., Rieffe, C., \& Crone, E. A. (2016). Peer influence on prosocial behavior in adolescence. Journal of Research on Adolescence, 26(1), 90-100. doi: 10.1111/jora.12173

Wang, M. T., \& Fredricks, J. A. (2014). The reciprocal links between school engagement, youth problem behaviors, and school dropout during adolescence. Child Development, 85(2), 722-737. doi: 10.1111/cdev.12138

Wheeler, S. B. (2010). Effects of self-esteem and academic performance on adolescent decision-making: an examination of early sexual intercourse and illegal substance use. Journal of Adolescent Health, 47(6), 582-590. doi: 10.1016/j.jadohealth.2010.04.009.

\section{ВРШЫАЧКИ ПРИТИСАК И АКАДЕМСКО ПОСТИГНУЋЕ КАО ПРЕДИКТОРИ РИЗИЧНОГ ПОНАШАЫА АДОЛЕСЦЕНАТА}

Оливера Кнежевић Флорић, Александра Павловић, Стефан Нинковић Универзитет у Новом Саду, Филозофски факултет, Нови Сад, Република Србија

\section{Резиме}

Будући да научни докази показују да су адолесценти способни за процену ризика које носи њихово понашање, истраживачи су почели да траже алтернативна објашњења ризичних избора младих. Вршњачки односи представљају једну од детерминанти социјалног понашања адолесцената. Адолесценти не само да желе да се друже са вршњацима сличних интересовања него вршњачки односи представљају утицајан агенс социјализације. Међутим, вршњаци могу имати и негативан утицај на ставове, одлуке и понашање адолесцената. За неке младе људе, употреба психоактивних супстанци, делинквенција и сексуална активност могу представљати напоре да се ускладе са нормама групе и да демонстрирају посвећеност и лојалност другим члановима групе. Претходна истраживања идентификовала су негативна школска искуства као фактор који повећава вероватноћу испољавања ризичних понашања. У том смислу, подстицање академског постигнућа је полазна основа бројних превентивних програма. Имајући у виду да у адолесценцији долази до смањења академске мотивације, постоји потреба за истраживањем односа академске успешности и ризичног понашања средњошколаца.

Циљ овог рада био је испитивање односа вршњачког притиска, академског постигнућа и ризичних понашања адолесцената. Истраживање је спроведено на узорку од 181 ученика (68\% женског пола) другог разреда средњих школа. Подаци су прикупљени применом упитника намењеног испитивању вршњачког притиска и ризичних понашања адолесцената, као и социодемографских варијабли. Академско постигнуће је операционализовано као просечна процена на крају првог полугодишта другог разреда. Добијени резултати показују да је конзумирање алкохола најприсутнији облик ризичног понашања адолесцената. Логистичка регресиона анализа је показала да вршњачки притисак и академско постигнуће оставарују ефекте на вероватноћу испољавања појединих видова ризичног понашања адолесцената. Резултати спроведеног истраживања могу имати импликације за унапређење програма превенције ризичних понашања у адолесценцији. 